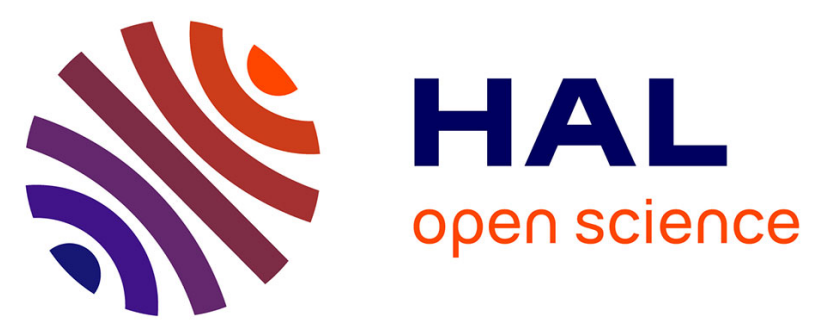

\title{
Changing landscapes of Southeast Asia and rodent-borne diseases: decreased diversity but increased transmission risks
}

Serge Morand, Kim Blasdell, Frédéric Bordes, Philippe Buchy, Bernard Carcy, Kittipong Chaisiri, Yannick Chaval, Julien Claude, Jean-Francois Cosson,

Marc Desquesnes, et al.

\section{To cite this version:}

Serge Morand, Kim Blasdell, Frédéric Bordes, Philippe Buchy, Bernard Carcy, et al.. Changing landscapes of Southeast Asia and rodent-borne diseases: decreased diversity but increased transmission risks. Ecological Applications, 2019, pp.e01886. 10.1002/eap.1886 . hal-02105014

\section{HAL Id: hal-02105014 \\ https://hal.science/hal-02105014}

Submitted on 19 Apr 2019

HAL is a multi-disciplinary open access archive for the deposit and dissemination of scientific research documents, whether they are published or not. The documents may come from teaching and research institutions in France or abroad, or from public or private research centers.
L'archive ouverte pluridisciplinaire HAL, est destinée au dépôt et à la diffusion de documents scientifiques de niveau recherche, publiés ou non, émanant des établissements d'enseignement et de recherche français ou étrangers, des laboratoires publics ou privés.

$$
\text { Copyright }
$$




\section{Changing landscapes of Southeast Asia and rodent-borne diseases: decreased diversity but increased transmission risks}

Serge Morand, ${ }^{1,2,17}$ Kim Blasdell, ${ }^{3}$ Frédéric Bordes, ${ }^{4}$ Philippe Buchy, ${ }^{5,6}$ Bernard Carcy, ${ }^{7}$ Kittipong Chaisiri, ${ }^{2}$ Yannick Chaval, ${ }^{8}$ Julien Claude, ${ }^{4}$ Jean-François Cosson, ${ }^{9}$ Marc Desquesnes, ${ }^{10,11}$ Sathaporn Jittapalapong, ${ }^{12}$ Tawisa Jiyipong, ${ }^{10,13}$ Anamika Karnchanabanthoen, ${ }^{7,12}$ Pumhom Pornpan, ${ }^{10,14}$ Jean-Marc Rolain, ${ }^{13}$ And AnNelise Tran ${ }^{15,16}$

${ }^{1}$ CNRS - CIRAD, Faculty of Veterinary Technology, Kasetsart University, Bangkok, Thailand

${ }^{2}$ Department of Helminthology, Faculty of Tropical Medicine, Mahidol University, $420 / 6$ Ratchavithi Road, Ratchathevi, Bangkok 10400 Thailand

${ }^{3}$ CSIRO Health and Biosecurity Business Unit, Australian Animal Health Laboratory, 5 Portarlington Road, Geelong, Victoria 3220 Australia

${ }^{4}$ Institut des Sciences de l'Evolution, UMR CNRS-IRD-UM2, Université de Montpellier, 35095 Montpellier Cedex, France

${ }^{5}$ Virology Unit, Institut Pasteur in Cambodia, 5 Monivong Boulevard, Phnom Penh, Cambodia

${ }^{6}$ GlaxoSmithKline Vaccines, Gateway West, 150 Beach Road, Singapore City 189720 Singapore

${ }^{7}$ LBCMIEA4558 VAP, UFR Sciences Pharmaceutiques et Biologiques, Université de Montpellier, Montpellier, France

${ }^{8}$ Comportement et Ecologie de la Faune Sauvage, INRA, Chemin de Borde Rouge, Auzeville, 31326 Castanet-Tolosan Cedex, France

${ }^{9}$ BIPAR-INRA Biologie Moléculaire et Immunologie Parasitaires et Fongiques, ENVA Maisons Alfort, 7 Avenue du Général de Gaulle, 94704 Maisons-Alfort Cedex, France

${ }^{10}$ Department of Parasitology, Faculty of Veterinary Medicine, Kasetsart University, Bangkok, Thailand

${ }^{11}$ CIRAD-Bios, UMR17 InterTryp, Montpellier F-34000 France

${ }^{12}$ Faculty of Veterinary Technology, Kasetsart University, Bangkok, Thailand

${ }^{13}$ URMITE CNRS INSERM IRD, IHU Méditerranée Infection, Faculté de Médecine et de Pharmacie, Aix-Marseille Université, 27 Bd Jean Moulin, 13385 Marseille Cedex 5, France

${ }^{14}$ Center for Agricultural Biotechnology, Kasetsart University, Kamphaeng Saen Campus, Nakhon Pathom, Thailand

${ }^{15}$ CIRAD, UMR TETIS, F-34093 Montpellier, France

${ }^{16}$ CIRAD, UMR ASTRE, Montpellier, France

Citation: Morand, S., K. Blasdell, F. Bordes, P. Buchy, B. Carcy, K. Chaisiri, Y. Chaval, J. Claude, J.-F. Cosson, M. Desquesnes, S. Jittapalapong, T. Jiyipong, A. Karnchanabanthoen, P. Pornpan, J.-M. Rolain, and A. Tran. 2019. Changing landscapes of Southeast Asia and rodent-borne diseases: decreased diversity but increased transmission risks. Ecological Applications 00(00):e01886. 10.1002/eap.1886

Abstract. The reduction in biodiversity from land use change due to urbanization and agricultural intensification appears to be linked to major epidemiological changes in many human diseases. Increasing disease risks and the emergence of novel pathogens result from increased contact among wildlife, domesticated animals, and humans. We investigated the relationship between human alteration of the environment and the occurrence of generalist and synanthropic rodent species in relation to the diversity and prevalence of rodent-borne pathogens in Southeast Asia, a hotspot of threatened and endangered species, and a foci of emerging infectious diseases. We used data from an extensive pathogen survey of rodents from seven sites in mainland Southeast Asia in conjunction with past and present land cover analyses. At low spatial resolutions, we found that rodent-borne pathogen richness is negatively associated with increasing urbanization, characterized by increased habitat fragmentation, agriculture cover and deforestation. However, at a finer spatial resolution, we found that some major pathogens are favored by environmental characteristics associated with human alteration including irrigation, habitat fragmentation, and increased agricultural land cover. In addition, synanthropic rodents, many of which are important pathogen reservoirs, were associated with fragmented and human-dominated landscapes, which may ultimately enhance the opportunities for zoonotic transmission and human infection by some pathogens.

Key words: Babesia; Bartonella; habitat; hantaviruses; land use land cover; Leptospira; rodent-borne diseases; synanthropy; Trypanosoma.

Manuscript received 26 January 2018; revised 26 October 2018; accepted 4 December 2018. Corresponding Editor: Jonathan N. Pauli.

${ }^{17}$ E-mail: serge.morand@cirad.fr

\section{INTRODUCTION}

Increasing human alteration of landscapes from agricultural intensification and urbanization is of major concern in tropical ecosystems (Dirzo et al. 2014). Tropical 
forests are increasingly replaced by heavily modified forests, agricultural crops, rubber plantations, or pastures for livestock (Jones et al. 2013, Warren-Thomas et al. 2015), with recent estimates suggesting that only $24 \%$ of extant tropical forests are considered intact and $46 \%$ are fragmented (Lewis and Maslin 2015). Such dramatic habitat changes are linked to accelerated biodiversity loss (Dirzo et al. 2014), which has been linked to major changes in the epidemiology of human diseases (Jones et al. 2013): increased disease risks and the emergence of novel pathogens resulting from increased contact among wildlife, domesticated animals, and humans (LloydSmith et al. 2009, Luis et al. 2013, Civitello et al. 2015, Olival et al. 2017).

Southeast Asia is a tropical region where biodiversity is at risk from of human activities and anthropogenic land-use change (Sodhi et al. 2004, Wilcove et al. 2013, Morand et al. 2017). Regional infectious diseases have also received considerable attention (Coker et al. 2011, Morand et al. 2014), with the emergence and spread of several significant viral zoonoses in recent decades (e.g., Nipah virus, avian influenza viruses, SARS-CoV, etc.). At a broad-scale, recent work has found that the number of recorded zoonotic disease outbreaks was positively linked to the number of threatened mammals and bird species found in SEA countries.

Despite the observed decline in biodiversity in disturbed habitats, the abundance of certain small mammals, and most notably synanthropic rodents, increases in fragmented and deforested environments (Froeschke and Matthee 2014, Rubio et al. 2014, Morand et al. 2015). This appears to be the result of increased availability of food sources (e.g., rice fields, human waste) or artificial structures that provides greater enhance from predators (e.g., covered drains; Morand et al. 2015). In such environments, a high prevalence of infection is often found in these rodent species (Suzán et al. 2009, McCauley et al. 2015). As highly permissive pathogen reservoirs, with a fast life histories, the high abundance reached by synanthropic rodents should increase contact rates between individuals and may boost pathogen transmission in human dominated habitats (Han et al. 2015). This is supported by the high prevalence of infection by some pathogens observed in these species in such environments (Suzán et al. 2009, McCauley et al. 2015).

Surprisingly, despite rodents being the dominant vertebrate species in many of these altered tropical systems and the key hosts for numerous zoonotic microparasites (i.e., viruses, bacteria, and protists) (Meerburg et al. 2009, Han et al. 2015), consistent patterns between habitat fragmentation and deforestation with the epidemiology of multiple rodent-borne diseases have yet to be determined (Blasdell et al. 2015), and studies that address the spatial context of pathogen circulation are lacking (Jones et al. 2013). Indeed, few studies have simultaneously considered the dynamics of microparasite diversity in rodent populations, despite the availability of numerous single pathogen species studies (Bordes et al. 2015a,b). To explore the links between altered habitats and rodent communities and the diversity and prevalence of microparasites in Southeast Asia, we used a large data set comprising microparasite screening results from murid rodents. Several species of the microparasites surveyed (hantaviruses, Leptospira spp., Bartonella spp., Trypanosoma spp., and Babesia spp.) are linked to serious human diseases (i.e., rodent-borne diseases) such as haemorrhagic fever with renal syndrome (HFRS), leptospirosis, bartonellosis, trypanosomosis, and babesiosis, many of which are recorded as emerging in Southeast Asia (Tangkanakul et al. 2005, Truc et al. 2013, Watt et al. 2014). These microparasites were investigated at seven localities in three countries of mainland Southeast Asia and were analyzed in conjunction with land cover maps (Morand et al. 2015; during 1987 to 2008), enabled the estimation of land use and land cover change (deforestation, conversion to agriculture land, and to human development [e.g., houses and roads]; Morand et al. 2015).

Our first aim was to identify rodents and rodent-borne microparasites that occurred across landscapes and localities, and to explore patterns of co-occurrence. For this, we used nested analyses (Nieberding et al. 2005) to explore the pattern of (1) rodents and (2) rodent microparasites among localities, and the nested pattern of (3) rodent-borne pathogens among rodent species. Second, we analyzed land cover at two spatial scales: across locations, a coarse spatial resolution, and within locations, a fine spatial resolution (i.e., at the location where each individual rodent was trapped). Our analyses at a low spatial resolution allowed the investigation of the effects of land use characteristics at the locality level on total microparasite species hosted by rodent communities. We hypothesized that increased human development and agricultural land use would decrease the diversity of rodent-borne diseases (Wood et al. 2017). Due to the observed positive relationship between host species richness and parasite species richness (Dunn et al. 2010, Lafferty 2012, Morand et al. 2014, Johnson et al. 2015, 2016), we hypothesized a decline in overall rodent diversity in human-altered landscapes and/or a decline of their microparasite diversity in relation to the decline of biodiversity, especially among arthropod vectors. We also predicted that increasing human alteration of habitats would favor synanthropic rodents and, therefore, the microparasites frequently associated with them (Rubio et al. 2014, Kosoy et al. 2015), representing an ongoing transmission risk in the changing environments of Southeast Asia (Bordes et al. 2016). At fine spatial resolution, we explored the relationships between the structure of the proximal surrounding landscape characteristics and the occurrence of individual rodents infected by microparasites including zoonotic species. As landscape spatial heterogeneity alters host abundance and distribution, the resulting surrounding spatial structure should also affect the transmission of microparasites (Page et al. 2001, Su et al. 2009, Ramsey et al. 
2012, Froeschke and Matthee 2014). Because generalist and synanthropic species are highly favored in fragmented areas (Morand et al. 2015), we hypothesized that an increase in spatial heterogeneity would increase transmission and, consequently, infection of synanthropic rodents, particularly habitat generalists, which may ultimately increase the risk of spillover to humans.

\section{Materials And Methods}

\section{Study sites}

Seven different sites in three countries (Thailand, Cambodia, and Lao PDR) were investigated (Fig. 1). Rodents were trapped in the Thai provinces of Buriram $\left(14.89^{\circ} \mathrm{N}, 103.01^{\circ} \mathrm{E}\right)$, Loei $\left(17.39^{\circ} \mathrm{N}, 101.77^{\circ} \mathrm{E}\right)$, and Nan $\left(19.15^{\circ} \mathrm{N}, 100.83^{\circ} \mathrm{E}\right)$, the Laotian provinces of Champasak $\left(15.12^{\circ} \mathrm{N}, 105.80^{\circ} \mathrm{E}\right)$ and Luang Prabang $\left(19.62^{\circ} \mathrm{N}, 102.05^{\circ} \mathrm{E}\right)$, and the Cambodian provinces of Mondulkiri $\left(12.04^{\circ} \mathrm{N}, 106.68^{\circ} \mathrm{E}\right)$ and Preah Sihanouk $\left(10.71^{\circ} \mathrm{N}, 103.86^{\circ} \mathrm{E}\right)$ in 2008 and 2009.

\section{Rodent trapping}

Trapping sessions were conducted twice annually (in the wet season between June and October, and in the dry season between December and March) over a two-year period (2008 to 2009). At each location, the same trap lines were trapped over a four-night period during each trapping session, with 30 lines of 10 traps $(10 \mathrm{~m}$ between traps) placed in three different habitats, namely (1) forests and mature plantations, (2) non-flooded lands or fields (shrubby waste land, young plantations, orchards), (3) lowland paddy rice fields (cultivated floodplain). This corresponded to a total of 1,200 trap nights per trapping session. Locally made live traps were used and the lines were placed in the same positions during each trapping session using GPS coordinates. Villages and isolated houses, which corresponded to a fourth habitat category, human settlement, were also sampled opportunistically, but with roughly similar sampling effort among localities, using cage traps distributed to residents (see Appendix S1; Morand et al. 2015). Captured rodents were identified to species in the field using morphological criteria, but were confirmed using molecular methods. Sixteen primary species of rodents were trapped with a total of 2,072 individuals (see Appendix S1: Table S1 for details).

\section{Land use and land cover}

For each locality (years 2007-2008), high spatial resolution $(2.5 \mathrm{~m}$ in panchromatic mode and $10 \mathrm{~m}$ in multispectral mode) SPOT 5 satellite images were acquired (CNES 2009, distributed by Astrium Services/Spot Image S.A., France; see Morand et al. 2015). SPOTDigital Elevation Model (DEM) with a spatial resolution of $20 \mathrm{~m}$ together with SRTM (Shuttle Radar
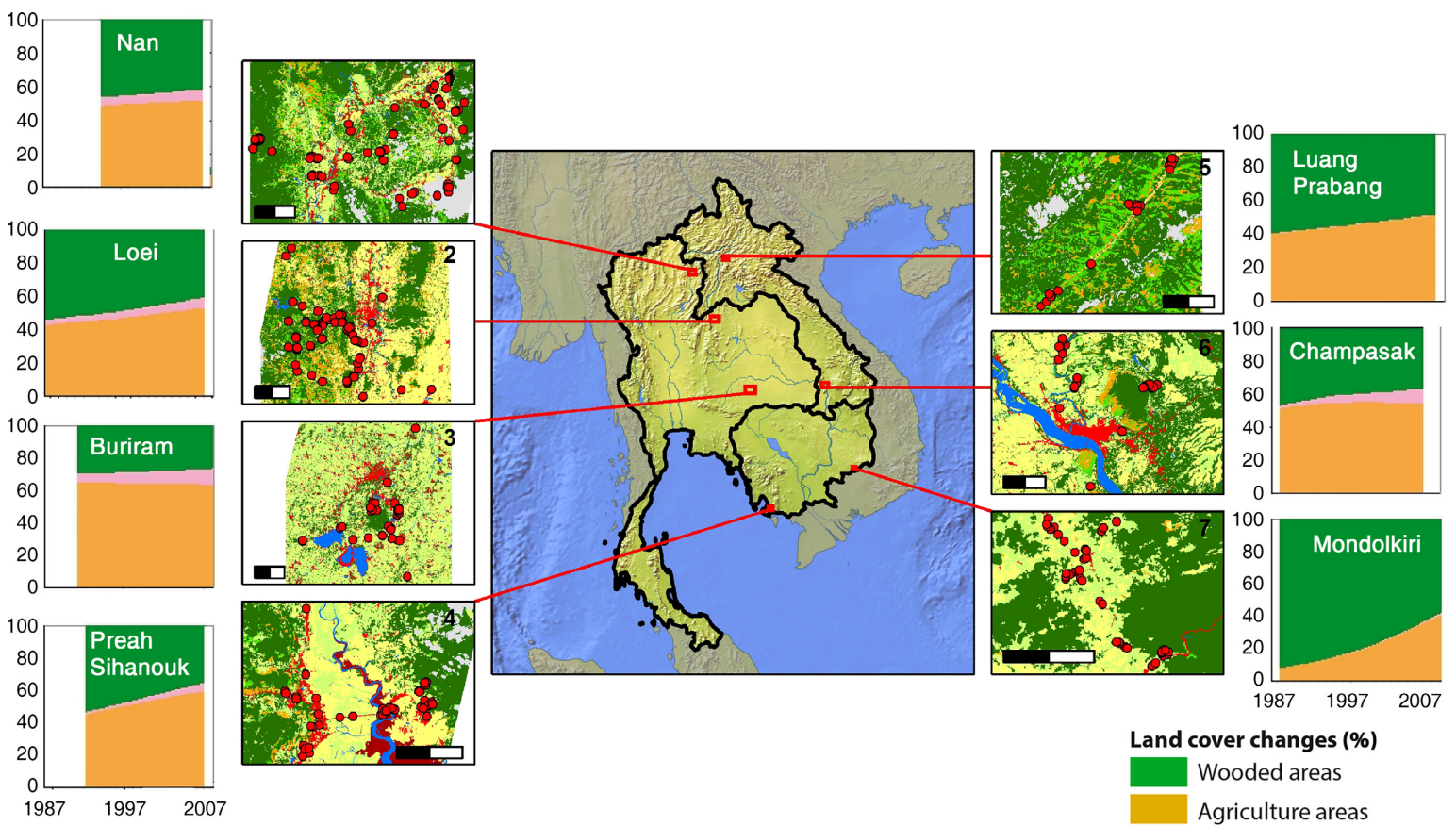

Land cover changes $(\%)$

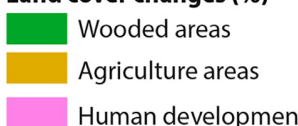

FIG. 1. Map of Southeast Asia showing simplified land covers the temporal dynamics of land use land cover changes over the last $22 \mathrm{yr}$ in relation to sample locations (red dots). Scale bars show distance ( $2 \mathrm{kms})$. 
Topography Mission) were also acquired. For each locality, the SPOT scene was classified into different land-cover types using an object-based approach. The land-cover maps and the DEM were integrated into a GIS in order to compute landscape metrics for each trapping site (see Appendix S1: Tables S2 and S3).

To describe the landscape surrounding the trapping location of each individual rodent, land cover metrics were calculated within a $100 \mathrm{~m}$ radius. These metrics included: cover of forest (Forest), cover of agriculture on steep land (Agri steep), cover of agriculture on flat land (Agri flat), cover of irrigated land (Irrigated), and human development are given in percent. We used patch density, the number of patches of different land cover types within a $100 \mathrm{~m}$ radius (for more details, see Morand et al. 2015), as a proxy for habitat diversity. We also edge density, the sum of the ratios of edge length to patch size for each patch, to represent relative habitat fragmentation. The mean values of these metrics were then calculated for each individual rodent (with trap GPS positioning in the middle of each trapping lines, i.e., with a precision at least less than $100 \mathrm{~m}$ ).

\section{Pathogen screening}

Rodents were screened for several species of viruses and bacteria hosted by rodents, including the major zoonotic pathogens: hantavirus (species not determined, see Appendix S1: Table S5), protists of the genus Trypanosoma (namely $T$. lewisi and $T$. evansi, both zoonotic, see Appendix S1: Table S6), and Babesia (namely B. microti and Babesia sp. BIC002, all zoonotic, see Appendix S1: Table S7), bacteria of the genus Bartonella (the zoonotic species B. rattimassiliensis, B. tribocorum, and $B$. elizabethae, and the non-zoonotic species B. musii, B. laosensis, B. phoceensis, B. queenslandensis, and B. coopersplainsensis; see Appendix S1: Table S8) and the genus Leptospira (L. borgpetersenii, L. interrogans, L. kirschneri, and L. weilli, all zoonotic, see Appendix S1: Table S9).

Original serological and genetic data concerning these rodent-borne pathogens have been published previously (Appendix S1: Table S10; Blasdell et al. 2012, Cosson et al. 2014, Jiyipong et al. 2015, Pumhom et al. 2015, Karnchanabanthoeng et al. 2017).

\section{Statistical analyses}

From the molecular screening of microparasites from rodents across seven locations in SEA and past and present maps of land use, we investigated (1) the nestedness of microparasites and rodents among localities, and of microparasites among their rodent hosts; (2) the effects of actual land use land cover and their shifting change on the community assemblages of rodents and their microparasites among localities, and using multivariate analyses; (3) the actual occurrence of the main rodent species and their main microparasites in relation to the actual surrounding landscape at the level of the trapping sites, and using general linear mixed models.

We measured nestedness for three matrices: the presence/absence $(0 / 1)$ of each rodent species among the seven localities; the presence/absence of each microparasite species among the seven localities; the presence/absence of each microparasite among each rodent species (see Appendix S1: Table S10). The nestedness analysis of microparasite species among rodent species was used to identify the main rodent-microparasite co-occurrences (summarized in Appendix S1: Table S9). We used the package vegan version 2.3-0 implemented in $\mathrm{R}(\mathrm{R}$ Development Core Team, Vienna, Austria). The NODF formula was used as a measure of nestedness (AlmeidaNeto et al. 2008), which returns values between 0 and 100. As nestedness can be biased by the size of the presence/absence matrix, we compared the results to null models, in which the values of presence/absence are redistributed at random with 999 replicates simulated.

To visualize the link between past land use changes and current land use land cover, we performed a principal component analysis (PCA) among the seven localities (Legendre and Legendre 2012). The variables included were forest cover, agriculture cover, human development, patch density, and edge density; three additional variables, the rate of deforestation, the rate of increased agricultural land, and the rate of increased human development, allowed the effects of land use changes over the last three decades. The estimation of these three rates of land use changes was obtained from reconstruction of past land use over the last three decades (Appendix S1: Table S4). We used the first component of the PCA as an index to human-domination. We also performed canonical correspondence analyses on the effects of actual landscape structure (forest cover, agriculture cover, human development, habitat diversity, habitat fragmentation) or the effects of shifting landscape structure (rate of deforestation, rate of increased agricultural land, rate of increased human development, rate of change in habitat fragmentation, rate of change in habitat diversity) on the community structure of total virus, bacteria, and protist species (i.e., microparasite species) and the ones that are transmitted to humans (i.e., rodent-borne pathogens) per locality. We used the package vegan implemented in $\mathrm{R}$. The values of inertia (the partitioning of mean squared contingency coefficient) were used to compare the responses of the type of the microparasite communities (total or rodent-borne pathogens) to either the actual landscape structure or the shifting landscape structure.

To analyze the occurrence of rodents, we modeled the probability of presence/absence of a species as a function of several environmental indices with a logistic regression, GLMM with logit function and random effects (for sites), using package lme4 implemented in R. Similarly, to analyze the infection of rodents, we modeled the probability of presence/absence of microparasites as a function of the same environmental indices with a 
logistic regression, GLMM with logit function and random effects (for locality), using package lme4 implemented in $\mathrm{R}$ (cases in each logistic regression were infected or non-infected individual rodents). Due to statistical constraints, this analysis was only performed on the seven most prevalent microparasites. The initial model included the environmental indices related to the habitat structure, and calculated for a buffer of $100 \mathrm{~m}$ for each individual rodent trapped: agriculture with high topographical relief, agriculture low topographical relief, irrigated agricultural land, forest, human development, patch density, and edge density. No interactions were added among the independent variables.

We evaluated support for competing models by investigating the relationship between the prevalence of each microparasite and all explanatory variables of interest. We used likelihood-based methods to quantify the alternative models and to estimate their parameters. We used the Akaike information criterion adjusted for sample size $\left(\mathrm{AIC}_{\mathrm{c}}\right)$ to assess the relative information content of the models. Selection of the best competing models was made using package glmulti version 1.0.7 2 (Calcagno and de Mazancourt 2010) implemented in R, which allows the exploration of all models using automated model selection and model-averaging procedure using a genetic algorithm. Visualization of the predicted responses, rodent occurrence and microparasite prevalence, was made using the packages sjmisc, sjlabelled, and sjPlot.

\section{RESUlTS}

All matrices of nestedness (presence/absence of rodent species among localities, microparasite species among localities, microparasite species among rodent species [Appendix S1: Table S11]) were statistically nested, with nestedness values (NODF) of 56.1 for rodent species among localities $(P<0.01$, Fig. 2A), 63.8 for microparasite species among localities $(P<0.01$, Fig. $2 \mathrm{~B})$, and 64.96 for microparasite species among rodent species $(P<0.01$, Fig. 2C). Among rodent species, the nested core group of species consisted of the synanthropic Rattus tanezumi, which occurred in all localities, and four other rodent species (Rattus exulans, Berylmys berdmorei, Bandicota indica, and Mus cookii) that were observed in at least six localities, (Fig. 2A). Of the microparasites tested, the nested core group consisted of the emerging protist species Trypanosoma lewisi (detected in all localities), hantavirus and Babesia microti Kobe type (each detected at least in six localities), and the zoonotic bacteria Leptospira borgpetersenii, L. interrogans, and Bartonella rattimassiliensis (each detected in five localities; Fig. 2B).

Two synanthropic species, $R$. tanezumi and $R$. exulans, and three agricultural-associated species, Bandicota savilei, B. indica, and Mus cookii were found to be hosts of the rodent-borne microparasites surveyed, constituting the nested core group of microparasite hosts (Fig. 2C). The more generalist microparasites, which were detected in a large number of rodent species, were B. microti US, B. microti Kobe, L. borgpetersenii, L. interrogans, hantavirus, and T. lewisi, all of which are zoonotic, and the non-zoonotic B. queenslandensis. These zoonotic pathogens have all have been found to be hosted by the habitat-generalist and synanthropic species Rattus tanezumi (Fig. 2C).

\section{Land use and land cover}

Principal component analysis (Fig. 3) revealed the associations between habitat structure and habitat heterogeneity, where the first and second dimensions explain $95 \%$ of the total variance. Some locations were characterized by high forest cover (Mondulkiri and Luang Prabang) whereas others were characterized by high agriculture land cover (Buriram) and/or high level of fragmentation and patch density (Nan, Loei). Projecting past estimated rates of deforestation, increased urbanization and increased agriculture on the PCA showed (1) that the rate of deforestation is highly correlated with the rate of increased urbanization, which explained both the actual level of fragmentation and patch density, and (2) that the rate of increased agriculture was correlated with the rate of urbanization, which explained the actual levels of forest, agriculture, and human development. The first component of the PCA (Fig. 3) was used as an index to human domination.

\section{Coarse land cover characteristics and species richness}

While we found no relationship between the total number of rodent species present and any of the land cover characteristics investigated (all $P>0.10$ ), we detected a negative relationship between the total number of microparasite species in rodents and the percent of human development $\left(F_{1,5}=10.08, \quad R^{2}=0.67\right.$, $P=0.034$, Fig. 4A) and a positive trend between the total number of zoonotic microparasites and the percentage of forest cover $\left(F_{1,5}=4.63, \quad R^{2}=0.48\right.$, $P=0.084$, Fig. 4B). Moreover, we found a negative and strong association between the total number of zoonotic microparasites and the percentage of agriculture cover $\left(F_{1,5}=15.93, R^{2}=0.76, P=0.010\right.$, Fig. $\left.4 \mathrm{C}\right)$. We also detected a relationship between patch density, and the total number of zoonotic microparasite species and the percentage of agriculture cover $\left(F_{1,5}=6.01, R^{2}=0.55\right.$, $P=0.057$ ), although association was not significant when the total number (i.e., both zoonotic and non-zoonotic) of microparasites was considered $\left(F_{1,5}=4.479\right.$, $R^{2}=0.37, \quad P=0.0879$.). The number of zoonotic microparasite species was negatively associated with the human-domination index (i.e., first component of PCA of Fig. $3 ; F_{1,5}=7.16, R^{2}=0.59, P=0.044$, Fig. 4D).

These results were confirmed using the Canonical Component Analyses. The values of inertia increased from CCAs investigating the effects of actual landscape structure (forest cover, agriculture cover, built-up covers, 
A

B

C

Luang Prabang

Preah Sihanouk

Mondolkiri

Nan

Loei

Buriram

Pakse

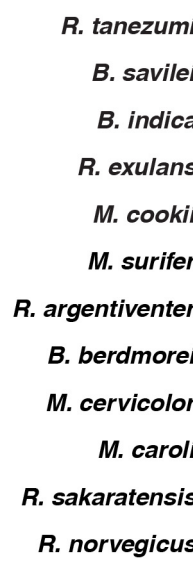

R. andamanensis

N. fulvescens

R. nitidus

B. bowersi

L. edwardsi
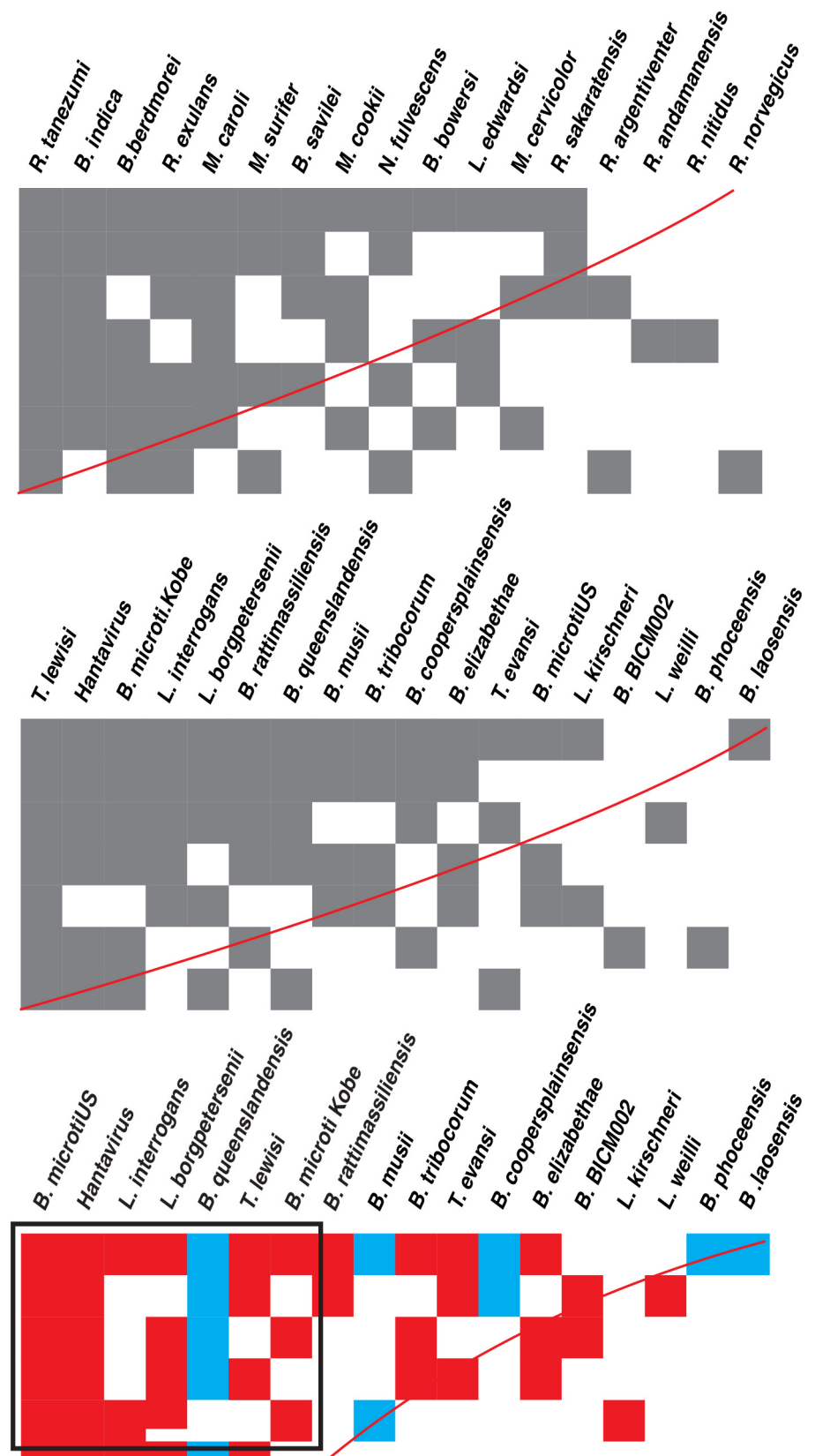
FIG. 2. Ordered matrices of presence (in black) or absence (white) of (A) rodent species by location, (B) microparasite species by location, and (C) microparasite by rodent species. Species are ordered from top to bottom with decreasing occurrence (A, B) or by rodent species for microparasites (C). For a fully nested scenario, all interactions would lie above the isocline (red line). Rodents: Bandicata indica, Bandicota savilei, Berylmys berdomrei, Berylmys bowersi, Leopoldamys edwarsi, Maxomys surifer, Mus caroli, Mus cervicolor, Mus cookii, Niviventer fulvescens, Rattus andamanensis, Rattus argentiventer, Rattus exulans, Rattus nititidus, Rattus norvegicus, Rattus sakeratensis, Rattus tanuzumi. Microparasites: Ha, Hantavirus $\dagger$, Trypanosoma evansi $\dagger$, Trypanosoma lewisi $\dagger^{\dagger}$, Babesia microt $\dagger_{\uparrow}^{\dagger}$ type US, Babesia microt $\dagger$ type Kobe, Babesia BIC002†, Bartonella coopersplainsensis, Bartonella elizabethae $\dagger$, Bartonella laosensis, Bartonella queenslandensis, Bartonella musii, Bartonella phoceensis, Bartonella rattimassiliensis $\dagger$, Bartonella triboco-

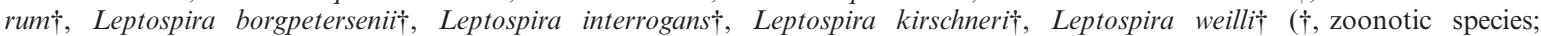
red, zoonotic microparasites; blue, non-zoonotic microparasites; with the nested core of co-occurrent rodents and microparasites).

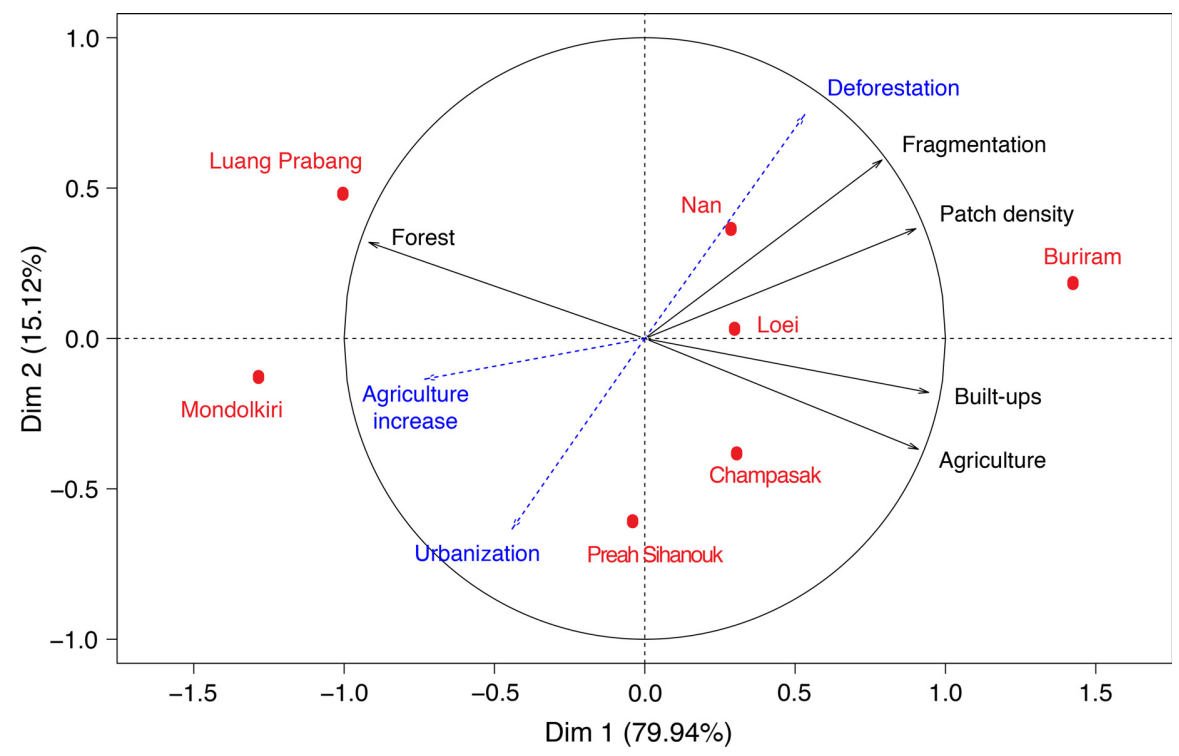

FIG. 3. Associations between habitat structure and heterogeneity and habitat change (based on presence/absence of each rodent species) among the seven study sites, on the first two axes of a principal component analysis (PCA). In dashed blue, estimated rates of deforestation, increased urbanization, and increased agriculture over the last $30 \mathrm{yr}$ are projected as supplementary variables on the first two axes of a PCA. The first and second dimensions explained $95 \%$ of the total variance.

habitat diversity, habitat fragmentation) on the community structure of all microparasites or rodent-borne pathogens (with similar values of inertia $=0.066$ ) to CCAs investigating the effects of shifting landscape structure (rate of deforestation, rate of increased cover in agriculture land, rate of increased cover in built-up areas, rate of change in habitat fragmentation, rate of change in habitat diversity) on the community structure of all microparasites and rodent-borne pathogens (with similar values of total inertia $=0.26$; only the effects of shifting landscape structure on the community structure of rodent-borne pathogens are represented on Fig. 5).

\section{Fine-scale habitat characteristics and rodent occurrence and pathogen infection}

Modified landscapes and environmental structures around the trapped rodents strongly influenced the probability of occurrence of each of the five species in the nested core group of rodents (Table 1, Fig. 6). The synanthropic species Rattus tanezumi and Rattus exulans were associated with urbanized areas (Fig. 6A) and deforested environments (Fig. 6D). The agricultural- associated species Bandicota savilei and Mus cookii were also found more often in locations with agriculture low topographical relief (Fig. 6B, E), while B. indica was common in highly fragmented areas (Fig. 6C).

Highly modified landscapes around the trapped rodents strongly impacted the probability that rodents were infected by zoonotic pathogens (Table 2, Fig. 7). The prevalence of five pathogens was linked to humandevelopment habitats (hantavirus, L. borgpetersenii, L. interrogans, B. microti Kobe, and T. lewisi; Table 2). The occurrence of the bacteria $L$. interrogans was primarily associated with irrigated agricultural cover, but also with decreasing agriculture cover on flat land (Table 2, Fig. 7B). The occurrence of T. lewisi, like hantavirus, was associated with agricultural cover on steep land, but also with human development and irrigated land (Table 2, Fig. 7A, E). Leptospira borgpetersenii was associated with irrigated agricultural land and decreased patch diversity (Table 2, Fig. 7D). The prevalence of $B$. microti US was independent of any environmental characteristics. Interestingly, the predicted prevalence of the non-zoonotic $B$. queenslandensis was negatively associated with human-dominated habitats; the predicted 
A

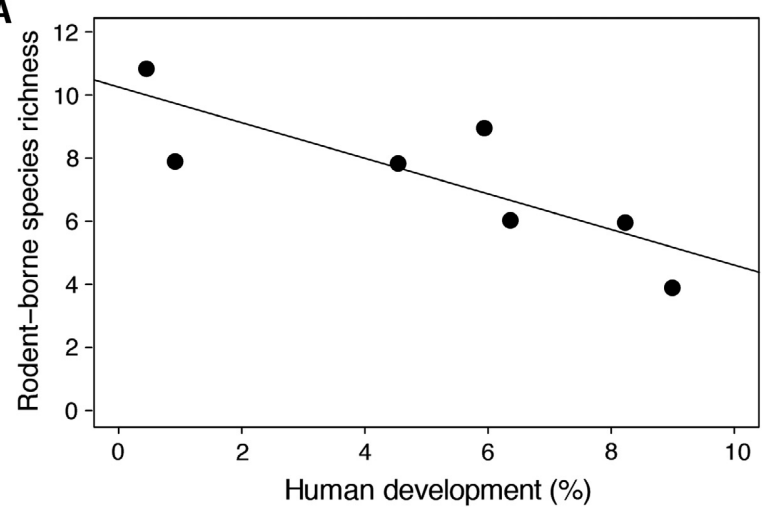

C

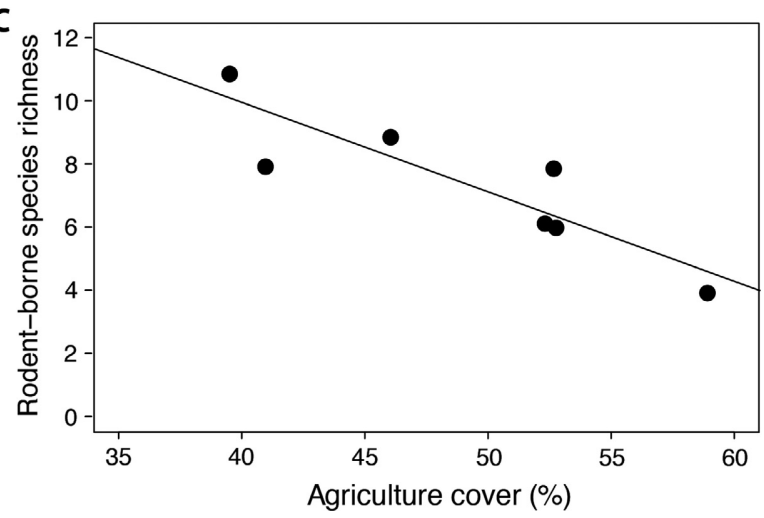

B

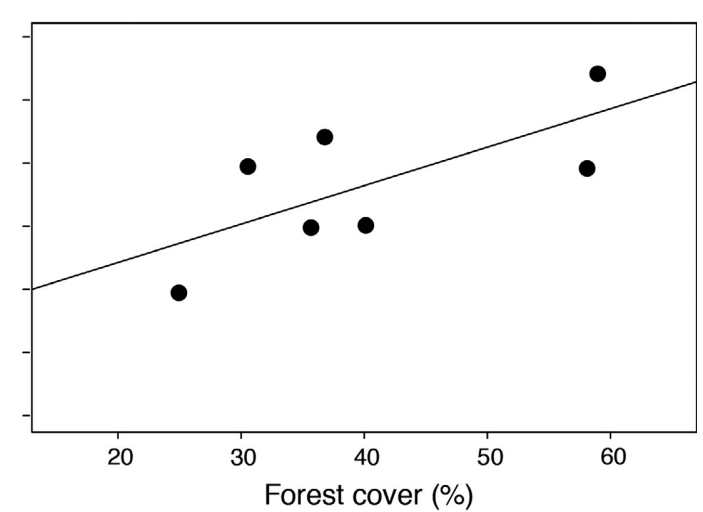

D

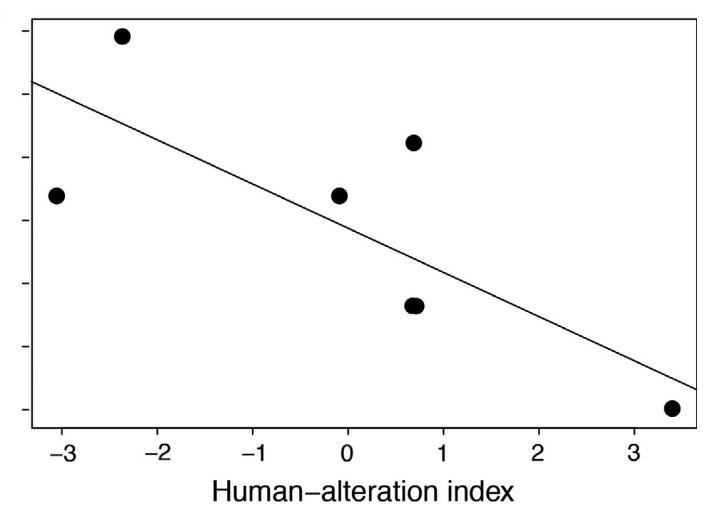

FIG. 4. Relationships between zoonotic microparasite species richness and percent of area as (A) human development, (B) forest cover, (C) agriculture cover, and (D) by human-domination index (first axis of Principal Components Analysis; see Fig. 3).

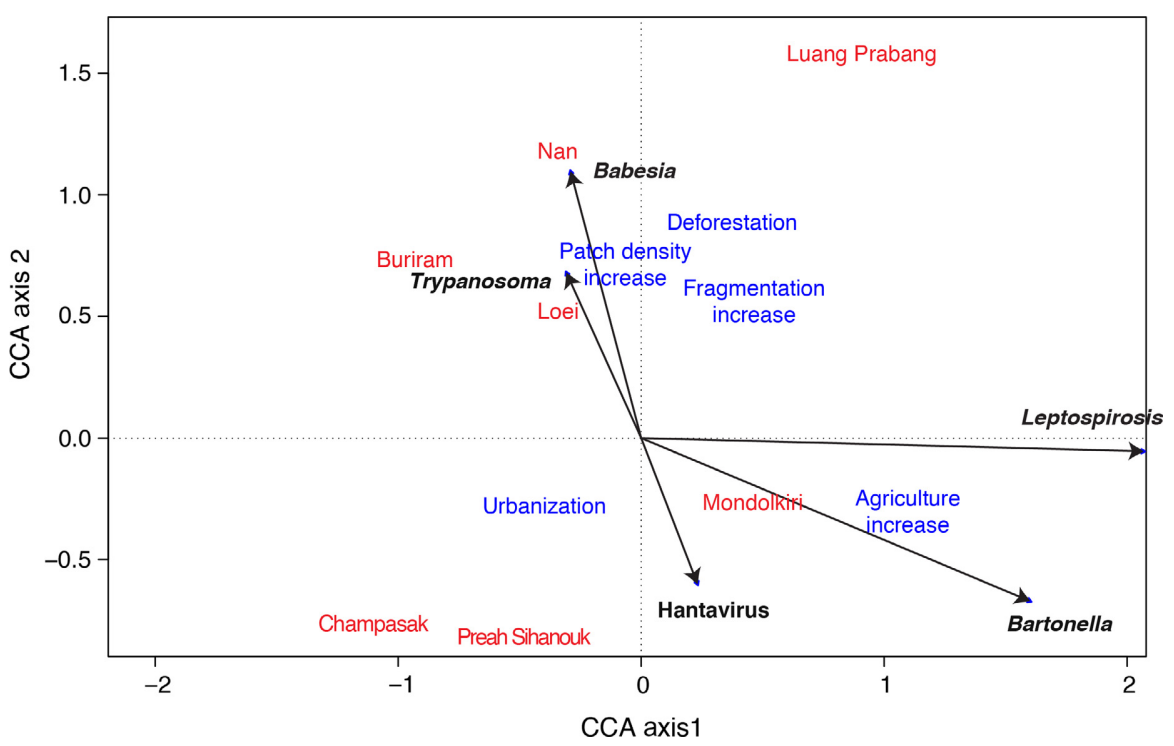

FIG. 5. Biplot of the canonical component analysis representing the effects of shifting landscape structure (rates of deforestation, increased agriculture land, human development, habitat fragmentation, and patch density) on the community structure of rodent-borne pathogens (Hantavirus, Leptospira, Bartonella and Babesia) (total inertia $=0.26$ ) among the seven sites investigated. 
TABLE 1. Results of the best GLMM (with logit link function and locality as random factor) explaining the occurrence of the five rodent species found to have the highest microparasite species richness (see Fig. 2C) from seven localities in Thailand, Lao PDR, and Cambodia, as a function of surrounding habitat characteristics around individual trapped rodents obtained from land cover layers (see Appendix S1).

\begin{tabular}{|c|c|c|c|}
\hline $\begin{array}{l}\text { Rodent species and explanatory } \\
\text { surrounding habitat characteristics }\end{array}$ & Estimate & $P$ & Log likelihood, deviance \\
\hline Rattus tanezumi & & & $-81.1,182.5(281)$ \\
\hline Human development cover & $6.04(1.80)$ & 0.0008 & \\
\hline Edge density & $0.004(0.001)$ & 0.01 & \\
\hline Agriculture on flat land cover & $1.16(0.72)$ & 0.11 & \\
\hline R. exulans & & & $-228.3,580.9(419)$ \\
\hline Human development cover & $18.84(3.34)$ & $<0.0001$ & \\
\hline Agriculture on steep land & $8.25(1.60)$ & $<0.0001$ & \\
\hline Agriculture on flat land cover & $8.05(1.46)$ & $<0.0001$ & \\
\hline Irrigated agriculture cover & $9.71(1.90)$ & $<0.0001$ & \\
\hline Edge density & $0.006(0.002)$ & 0.008 & \\
\hline Forest cover & $3.36(1.43)$ & 0.02 & \\
\hline Patch density & $-2.58(1.62)$ & 0.11 & \\
\hline Bandicota indica & & & $-46.6,105.0(277)$ \\
\hline Patch density & $3.51(1.41)$ & 0.01 & \\
\hline Agriculture on flat land cover & $4.36(2.09)$ & 0.04 & \\
\hline Forest cover & $5.13(2.6)$ & 0.049 & \\
\hline B. savilei & & & $-69.5,346.7(325)$ \\
\hline Agriculture on flat land cover & $5.65(1.01)$ & 0.049 & \\
\hline Patch density & $-18.2(4.03)$ & $<0.0001$ & \\
\hline Edge density & $0.028(0.006)$ & $<0.0001$ & \\
\hline Human development cover & $-34.3(10.0)$ & 0.0006 & \\
\hline Mus cookii & & & $-173.6,508.82(378)$ \\
\hline Agriculture on steep land & $7.54(0.10)$ & $<0.0001$ & \\
\hline Irrigated agriculture cover & $-18.50(2.93)$ & $<0.0001$ & \\
\hline Patch density & $7.12(1.91)$ & 0.0002 & \\
\hline Edge density & $-0.009(0.003)$ & 0.001 & \\
\hline
\end{tabular}

Notes: The initial models included the following explanatory variables: cover of agriculture on steep land, cover of agriculture on flat land, cover of irrigated agriculture, cover of forest, cover of human development, patch density, edge density. Estimate of the logit function is shown with SD in parentheses; residual deviance is shown with degrees of freedom in parentheses. In bold, $\mathrm{P}<0.5$.

prevalence increased with the decrease of the cover of agriculture on flat land (Table 2, Fig. 7).

\section{Discussion}

Our results confirmed our prediction that decreasing forest cover and increasing agricultural land, is associated with a decrease of the total microparasite species richness harbored by rodents, and a decrease of rodentborne pathogens. Our analyses also confirmed our prediction that observed habitat changes favor habitat-generalist and synanthropic rodents and their associated microparasites. These findings support other studies that have found synanthropic rodent species replace habitat and forest specialist species in heavily disturbed landscapes (McFarlane et al. 2012, Kosoy et al. 2015). Our findings also support the concept that increasing habitat fragmentation and resultant biodiversity loss on the epidemiology of zoonotic diseases (Levi et al. 2016). The increase of human domination on habitats may favor the density and abundance of synanthropic rodents, ultimately favoring the spread of the rodent-borne pathogens associated with them. Most importantly, we provide evidence that increasing landscape heterogeneity and human alteration of landscapes, favors infection of the synanthropic and generalist rodent species by generalist microparasite species that are significant to human health. Association with these rodent species, which are often abundant in human dominated landscapes in the tropics, could have important implication on the circulation and transmission of major pathogens for human populations.

We found that both rodent species and microparasite species were nested among localities, suggesting that species loss follows a common pattern in both rodents and their microparasites. In particular, increasing modification of land for human use increased habitat generalists and synanthropic rodents like $R$. tanezumi and $R$. exulans and the agriculture specialists B. indica, B. savilei, and $R$. argentiventer. Microparasite species were found to be nested both among localities and among rodent host species meaning that decreases or increases in their diversity are related both to habitat characteristics and rodent diversity. Increasing human alteration of the 

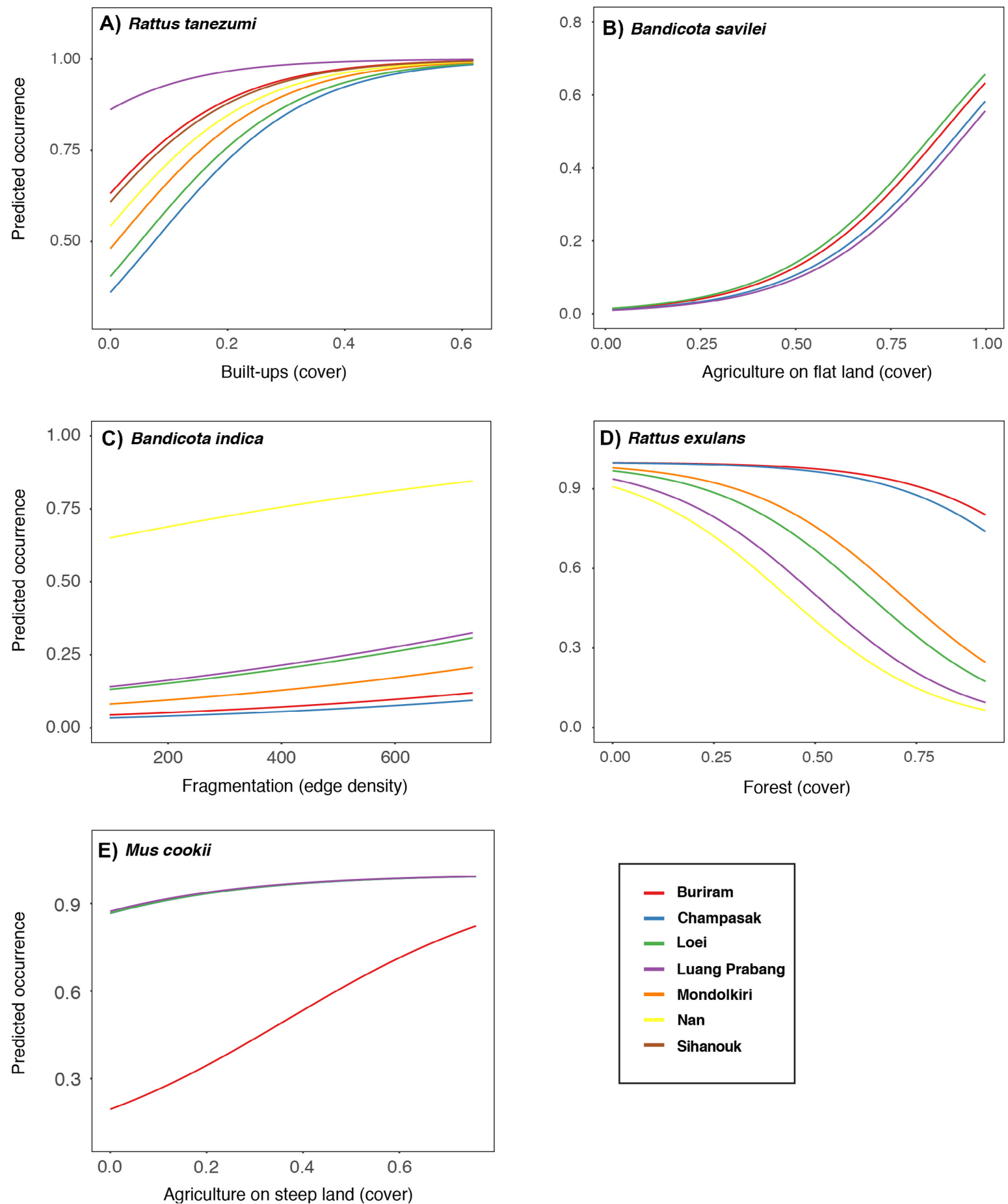

FIG. 6. Predicted occurrence by site of the nested core rodent species (see Fig. 2C) based on the best GLMM on surrounding habitat characteristics (see Table 1) for (A) Rattus tanezumi, (B) Bandicota savilei, (C) Bandicota indica, (D) Rattus exulans, and (E) Mus cookii, with locality as random factor.

landscape also supports host-generalist microparasite species, such as hantavirus, Trypanosoma, Leptospira, or some Bartonella spp., which are often hosted by numerous species, many of which are either habitat generalist or synanthropic in nature.
Our results, that local microparasite diversity is reduced in fragmented and urbanized landscapes is likely a result of an overall simplified community. Indeed, the presence, diversity and density of many rodent species are positively influenced by vegetation cover (Ernest 
TABLE 2. Results of the best GLMM (with logit link function and locality as random factor) explaining the occurrence of the six rodent-borne microparasites found to be the most prevalent in rodents from seven localities in Thailand, Lao PDR and Cambodia, as a function of surrounding habitat characteristics around individual trapped rodents obtained from land cover layers (see Appendix S1).

\begin{tabular}{|c|c|c|c|}
\hline $\begin{array}{l}\text { Microparasite and explanatory } \\
\text { surrounding habitat characteristics }\end{array}$ & Estimate & $P$ & Log likelihood, deviance \\
\hline Hantavirus & & & $-160.6,321.1(1360)$ \\
\hline Agriculture on steep land & $2.76(1.01)$ & 0.006 & \\
\hline Agriculture on flat land & $2.03(1.06)$ & 0.06 & \\
\hline Patch density & $-3.02(1.70)$ & 0.08 & \\
\hline Bartonella queenslandensis & & & $-120.1,240.1(1244)$ \\
\hline Agriculture on flat land & $-2.08(0.96)$ & 0.030 & \\
\hline Forest & $-1.64(1.13)$ & 0.15 & \\
\hline Leptospira interrogans & & & $-40.6,81.3(461)$ \\
\hline Agriculture on flat land & $-3.74(1.63)$ & 0.02 & \\
\hline Irrigated land & $2.48(1.22)$ & 0.04 & \\
\hline Patch density & $-5.73(3.03)$ & 0.06 & \\
\hline L. borgpetersenii & & & $-92.7,185.5(461)$ \\
\hline Patch density & $-1.02(0.49)$ & 0.035 & \\
\hline Fragmentation & $0.01(0.006)$ & 0.05 & \\
\hline Irrigated & $-0.04(0.02)$ & 0.08 & \\
\hline Trypanosoma lewisi & & & $-130.0,268.1(360)$ \\
\hline Agriculture on steep land & $3.45(1.30)$ & 0.008 & \\
\hline Human development cover & $4.85(2.32)$ & 0.036 & \\
\hline Irrigated & $3.11(1.56)$ & 0.045 & \\
\hline Patch density & $2.69(1.60)$ & 0.09 & \\
\hline Babesia microti US type & & & $-203.8,408.5(1268)$ \\
\hline Fragmentation & $-0.001(0.001)$ & 0.35 & \\
\hline B. microti Kobe type & & & $-72.4,144.8(1265)$ \\
\hline Fragmentation & $0.008(0.004)$ & 0.05 & \\
\hline Irrigated & $5.08(3.40)$ & 0.12 & \\
\hline
\end{tabular}

Notes: The initial models included the following explanatory variables: cover of agriculture on steep land, cover of agriculture on flat land, cover of irrigated agriculture, cover of forest, cover of human development, patch density, edge density. Estimate of the logit function is shown with SD in parentheses; residual deviance is shown with df in parentheses. In bold, $\mathrm{P}<0.5$.

et al. 2000, Baker et al. 2003), and human activities that reduce forest cover likely have strong implication on rodent populations and communities (Levi et al. 2016). It seems likely that arthropod vectors are also be impacted by these changes (Pumhom et al. 2015); with reducing host diversity, there should be a concomitant reduction in arthropod vector diversity as well. Thus, a reduction in the abundance or diversity of rodent hosts or vectors could affect transmission and lead to a reduction in the overall microparasite diversity. Moreover, vegetation cover and structure affect microclimatic characteristics (e.g., humidity, ambient temperatures, and solar radiation) all of which can have important implications on the free-living stages of Leptospira spp. and reduce the environmental persistence of many other pathogens, including hantavirus virions (Hardestam et al. 2008).

On the other hand, human alteration of the landscape can create favorable ecological conditions for the persistence and maintenance of some microparasites and their rodent hosts. For example, irrigation channels and drainage systems provide suitable conditions for Leptospira spp. survival (Ganoza et al. 2006), while microclimates generated by human structures can reduce solar radiation and increase the persistence of UV-sensitive pathogens such as hantaviruses (Cline et al. 2010). The selection of synanthropic rodents and the relative abundance that these species can reach in heavily modified landscapes should also promote the transmission of some of the pathogens they carry. Indeed, we suspect that this mechanism explains for the spatial patterning of four (hantavirus, L. interrogans, L. borgpetersenii, T. lewisi) of the five rodent-borne pathogens studied. All four were associated with synanthropic and agricultural habitat specialist rodents and each showed an increase in prevalence with either an increase in agricultural cover on steep land (primarily resulting from forest conversion), an increase in agriculture intensification through the increased use of irrigated land, or a decrease in the proportion of forest cover. Simplification of land cover with decreasing habitat diversity or increased fragmentation was also found to be associated with an increase in prevalence of some of these pathogens (i.e., B. rattimassiliensis, T. lewisi). In addition, of the Leptospira species investigated, only one appeared to decrease in prevalence as a result of increasing human landscape use. These analyses conducted at fine-scale spatial resolution confirm that the zoonotic transmission for certain 

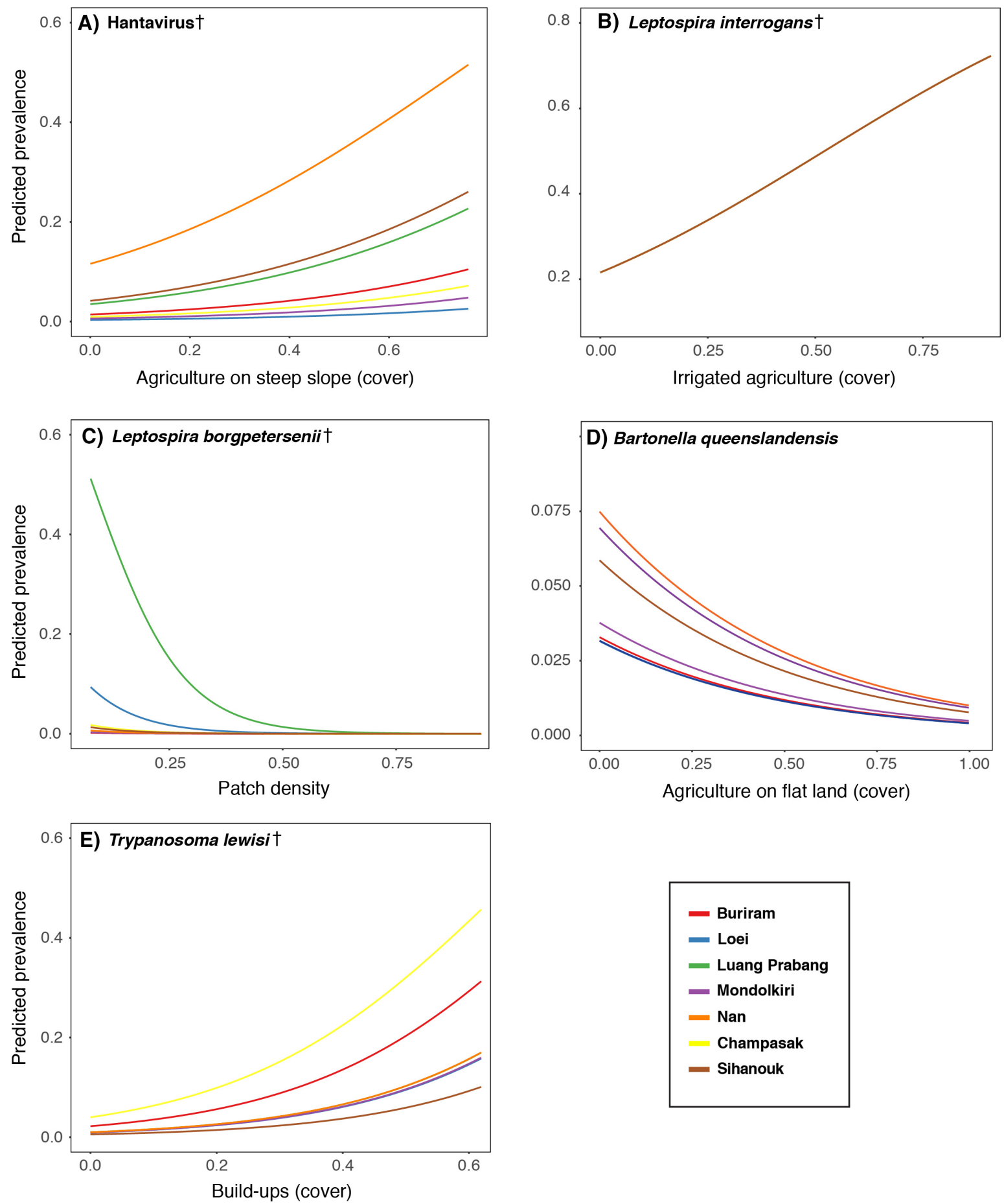

FIG. 7. Predicted prevalence of the nested core rodent-borne microparasites (see Fig. 2C) based on the best GLMM on surrounding habitat characteristics (see Table 2) explaining the infection of rodents by (A) hantavirus $\dagger$, (B) Leptospira interrogans $\dagger$, (C) Leptospira borgpetersenii†, (D) Bartonella queenslandensis, (E) Trypanosoma lewisi†, (†zoonotic species) (see Appendix S1: Table S9).

pathogens, likely increases in environments subjected to agriculture intensification, urbanization and forest conversion.
Our findings have implications for several rodentborne diseases that are considered reemerging or emerging diseases in Southeast Asia (Coker et al. 2011, 
Blasdell et al. 2015, 2016). Globally, China reports the highest number of human hantavirus cases annually, but only isolated cases have so far been reported from other Southeast Asian countries. However, as many murid species have been identified as hantavirus hosts, including several synanthropic species such as Bandicota indica, B. savilei, or $R$. tanezumi, increased human exposure may occur in these landscapes (Morand et al. 2015). Leptospirosis emerged in Thailand in the mid-1990s with a major outbreak occurring in 2000 (Tangkanakul et al. 2005). Pathogenic Leptospira species show no real host specificity toward particular rodent species, but differences in their habitat requirements can impact their occurrence, with $L$. interrogans linked to rodents living in humid habitats (rice fields and forests) and L. borgpetersenii to both humid and dry habitats (Cosson et al. 2014).

The number of human cases of bartonellosis has also been reported to have increased in Thailand, collectively caused by several Bartonella species hosted by rodents, in particular (Watt et al. 2014, Jiyipong et al. 2015, Klangthong et al. 2015). Bartonella species identified in human cases include B. elizabethae, B. rattimassiliensis, and B. tribocorum (Kosoy et al. 2010), which have each been found in at least one synanthropic rodent species: B. elizabethae in $R$. exulans and $R$. tanezumi; B. rattimassiliensis in $R$. tanezumi; B. tribocorum in $R$. exulans, $R$. tanezumi, and $R$. norvegicus (Jiyipong et al. 2015).

In the past decade, the number of reports of atypical cases of human Trypanosoma lewisi-like and Trypanosoma evansi infections increased considerably, particularly in Malaysia and Thailand (Truc et al. 2013). Pumhom et al. (2015), investigating the environmental niche of T. lewisi and T. evansi in rodents in the same localities as the present study, found a high prevalence of infection by $T$. lewisi in rodents living near human settlement and in areas with a high proportion of human development. They also demonstrated that infection of rodents by $T$. evansi was explained by increased landscape patchiness and high coverage of land by rain-fed agriculture. Together with the present results and the recent human case reported in Vietnam (Van Vinh Chau et al. 2016), this shows that land use changes in favor of agriculture and urbanization, present an increasing risk of spillover of trypanosomes to humans in this region.

Our study was designed to perform comparative analyses among sites. Such a comparative study lacks the explanatory power of long-term studies, but retrospective data on rodent-borne pathogens in Southeast Asia are scarce, and there have been no long-term studies performed in the countries investigated here. Our results emphasize the need for the implementation of long-term surveillance of rodent-borne pathogens and diseases in this rapidly changing region. Long-term studies would enable an in depth analysis of the epidemiological dynamics of rodent-borne diseases and how these vary with land use changes, climate changes, and socioeconomic changes. First, by using a comparative, time-series analyses of the hypothesized dilution effect, it would avoid "snapshot analyses" and potential biases by taking into account confounding effects (Salkeld et al. 2013, Civitello et al. 2015). Second, it would allow an assessment of how the turn-over of rodent-borne pathogens (or beta microparasite diversity) impacts the risk of emergence and/or epidemics of the infectious diseases that are linked to the favorable influences of habitat changes on synanthropic rodent species. Moreover, increasing the number of localities will permit to investigate the scaling effect of landscape on the pattern of community assemblages of rodents and rodent-borne pathogens assemblages at various levels from broad level to fine level (see Presley et al. 2010). A better understanding of all of these would greatly aid future predictions of human disease risk.

\section{ACKNOWLEDGMENTS}

We thank the CERoPath team and the drivers for their invaluable help during fieldwork. We thank Stéphane Dupuy (CIRAD) for image processing and Vincent Herbreteau (IRD) for GIS development. Authors' contributions: S. Morand, J. Claude, J. F. Cosson, and A. Tran designed the study. S. Morand, K. Blasdell, F. Bordes, K. Chaisiri, Y. Chaval, J. Claude, and J. F. Cosson performed the field sampling. K. Blasdell, P. Buchy, B. Carcy, J. F. Cosson, M. Desquesnes, A. Karnchanabanthoen, S. Jittapalapong, T. Jiyipong, P. Pornpan., and J. M. Rolain screened for microparasite detections. A. Tran developed the LULC. S. Morand analyzed the data and wrote the manuscript with input from all authors. Rodent species included in the study are neither on the CITES list, nor the Red List (IUCN). Animals were treated in accordance with the guidelines of the American Society of Mammalogists, and within the European Union legislation guidelines (Directive 86/609/EEC). Each trapping campaign was validated by the national, regional, and local health authorities. Approval notices for trapping and investigation of rodents were provided by the Ministry of Health Council of Medical Sciences, National Ethics Committee for Health Research (NHCHR) Lao PDR, number 51/ NECHR, and by the Ethical Committee of Mahidol University, Bangkok, Thailand, number 0517.1116/661. Philippe Buchy is currently an employee of GSK vaccines. This study was funded by the French ANR Biodiversity, grant ANR 07 BDIV 012 CERoPath project, and by the French ANR CP\&ES, grant ANR 11 CPEL 002 BiodivHealthSEA project. T. Jiyipong was supported by the Infectiopôle Sud. M. Desquesnes was supported by the Thailand International Cooperation Agency (TICA). SPOT images and SPOT DEMs were obtained with financial support of the ISIS (Incitation à l'utilisation Scientifique des Images SPOT) program operated by the French Space Agency512 (CNES).

\section{Literature Cited}

Almeida-Neto, M., P. Gumarães, P. R. Gumarães, R. D. Loyola, and W. Ulrich. 2008. A consistent metric for nestedness analysis in ecological systems: reconciling concept and measurement. Oikos 117:1227-1239.

Baker, P. J., R. J. Ansell, P. A. A. Dodds, C. E. Webber, and S. Harris. 2003. Factors affecting the distribution of small mammals in an urban area. Mammal Review 33:95-100.

Blasdell, K., J.-F. Cosson, Y. Chaval, V. Herbreteau, B. Douangboupha, S. Jittapalapong, Å. Lundqvist, J.-P. Hugot, 
S. Morand, and P. Buchy. 2012. Rodent-borne Hantaviruses in Cambodia, Laos PDR and Thailand. EcoHealth 8:432443.

Blasdell, K., et al. 2015. Progress on research on rodents and rodent-borne zoonoses in Southeast Asia. Wildlife Research 42:98-107.

Blasdell, K., V. Duong, M. Eloit, F. Chretien, S. Ly, V. Hul, V. Deubel, S. Morand, and P. Buchy. 2016. Evidence of human infection by new arenaviruses endemic to Southeast Asia. eLife 5:e13135.

Bordes, F., K. Blasdell, and S. Morand. 2015a. Transmission ecology of rodent-borne diseases: new frontiers. Integrative Zoology 10:424-435.

Bordes, F., et al. 2015b. Habitat fragmentation alters the properties of a host-parasite network: rodents and their helminths in South-East Asia. Journal Animal Ecology 84:1253-1263.

Bordes, F., A. Caron, K. Blasdell, M. de Garine Wichatitsky, and S. Morand. 2016. Forecasting potential emergence of zoonotic diseases in South-East Asia: network analysis identifies key rodent hosts. Journal of Applied Ecology 54:691-700.

Calcagno, V., and C. de Mazancourt. 2010. glmulti: An R package for easy automated model selection with (generalized) linear models. Journal Statistical Software 34:12.

Civitello, D. J., et al. 2015. Biodiversity inhibits parasites: Broad evidence for the dilution effect. Proceedings National Academy of Sciences USA 112:8667-8671.

Cline, B. J., S. Carver, and R. J. Douglass. 2010. Relationship of human behavior within outbuildings to potential exposure to Sin Nombre virus in Western Montana. EcoHealth 7:389 393.

Coker, R. J., B. M. Hunter, J. W. Rudge, M. Liverani, and P. Hanvoravongchai. 2011. Emerging infectious diseases in Southeast Asia: regional challenges to control. Lancet 377:599-609.

Cosson, J.-F., M. Picardeau, M. Mielcarek, C. Tatard, Y. Chaval, Y. Suputtamongkol, P. Buchy, S. Jittapalapong, V. Herbreteau, and S. Morand. 2014. Epidemiology of Leptospira transmitted by rodents in Southeast Asia. PLoS Neglected Tropical Diseases 8:e2902.

Dirzo, R., H. S. Young, M. Galetti, G. Ceballos, N. J. Isaac, and B. Collen. 2014. Defaunation in the Anthropocene. Science 345:401-416.

Dunn, R. R., T. J. Davies, N. C. Harris, and M. C. Gavin. 2010. Global drivers of human pathogen richness and prevalence. Proceedings of the Royal Society London B 277:2587-2595.

Ernest, S. K. M., J. H. Brown, and R. R. Parmenter. 2000. Rodents, plants, and precipitation: spatial and temporal dynamics of consumers and resources. Oikos 88:470-482.

Froeschke, G., and S. Matthee. 2014. Landscape characteristics influence helminth infestations in a peri-domestic rodent implications for possible zoonotic disease. Parasites and Vectors 7:393.

Ganoza, C. A., M. A. Matthias, D. Collins-Richards, K. C. Brouwer, C. B. Cunningham, E. R. Segura, R. H. Gilman, E. Gotuzzo, and J. M. Vinetz. 2006. Determining risk for severe leptospirosis by molecular analysis of environmental surface waters for pathogenic Leptospira. PLoS Medicine 3: e308.

Han, B. A., J. P. Schmidt, S. E. Bowden, and J. M. Drake. 2015. Rodent reservoirs of future zoonotic diseases. Proceedings National Academy of Science USA 112:7039-7044.

Hardestam, J., M. Karlsson, K. I. Falk, G. Olsson, J. Klingström, and A. Lundkvist. 2008. Puumala Hantavirus excretion kinetics in Bank Voles (Myodes glareolus). Emerging Infectious Diseases 14:1209-1215.
Jiyipong, T., S. Morand, S. Jittapalapong, and J. M. Rolain. 2015. Bartonella spp. infections in rodents of Cambodia, Lao PDR and Thailand: identifying risky habitats. Vector-Borne and Zoonotic Diseases 15:48-55.

Johnson, P. T. J., R. S. Ostfeld, F. Keesing, E. Biology, and B. Program. 2015. Frontiers in research on biodiversity and disease. Trends in Ecology and Evolution 18:1119-1133.

Johnson, P. T. J., C. L. Wood, M. B. Joseph, D. L. Preston, S. E. Haas, and Y. P. Springer. 2016. Habitat heterogeneity drives the host-diversity-begets-parasite-diversity relationship: evidence from experimental and field studies. Ecology Letters 19:752-761.

Jones, B. A., et al. 2013. Zoonosis emergence linked to agricultural intensification and environmental change. Proceedings National Academy of Science USA 110:8399-8404.

Karnchanabanthoeng, A., S. Morand, S. Jittapalapong, and B. Carcy. 2017. Babesia occurrence in rodents in relation to landscapes of mainland Southeast Asia. Vector-Borne and Zoonotic Diseases 18:121-130.

Klangthong, K., S. Promsthaporn, S. Leepitakrat, A. L. Schuster, P. W. McCardle, M. Kosoy, and R. Takhampunya. 2015. The distribution and diversity of Bartonella species in rodents and their ectoparasites across Thailand. PLoS ONE 10: $\mathrm{e} 0140856$

Kosoy, M., et al. 2010. Identification of Bartonella infections in febrile human patients from Thailand and their potential animal reservoirs. American Journal of Tropical Medicine and Hygiene 82:1140-1145.

Kosoy, M., L. Khlyap, J.-F. Cosson, and S. Morand. 2015. Aboriginal and invasive rats of genus Rattus as hosts of infectious agents. Vector-Borne and Zoonotic Diseases 15:3-12.

Lafferty, K. D. 2012. Biodiversity loss decreases parasite diversity: theory and patterns. Philosophical Transactions of the Royal Society B 367:2814-2827.

Legendre, P., and L. Legendre. 2012. Numerical ecology. Springer, New York, New York, USA.

Levi, T., A. L. Massey, R. D. Holt, F. Keesing, R. C. Ostfeld, and C. A. Peres. 2016. Does biodiversity protect humans against infectious disease? Comment. Ecology 97:536-546.

Lewis, S. L., and M. A. Maslin. 2015. Defining the Anthropocene. Nature 519:171-180.

Lloyd-Smith, J. O., D. George, K. M. Pepin, V. E. Pitzer, J. R. Pulliam, A. P. Dobson, P. J. Hudson, and B. T. Grenfell. 2009. Epidemic dynamics at the human-animal interface. Science 326:1362-1367.

Luis, A. D., et al. 2013. A comparison of bats and rodents as reservoirs of zoonotic viruses: are bats special? Proceedings of the Royal Society B 280:1471-2954.

McCauley, D. J., D. J. Salkeld, H. S. Young, R. Makundi, R. Dirzo, R. P. Eckerlin, E. F. Lambin, L. Gaffikin, M. Barry, and K. M. Helgen. 2015. Effects of land use on plague (Yersinia pestis) activity in rodents in Tanzania. American Journal of Tropical Medicine and Hygiene 92:776-783.

McFarlane, R., A. Sleigh, and T. McMichael. 2012. Synanthropy of wild mammals as a determinant of emerging infectious diseases in the Asian-Australasian region. EcoHealth 9:24-35.

Meerburg, B. G., G. R. Singleton, and A. Kijlstra. 2009. A Rodent-borne diseases and their risks for public health. Critical Review Microbiology 35:221-270.

Morand, S., S. Jittapalapong, Y. Supputamongkol, M. T. Abdullah, and T. B. Huan. 2014. Infectious diseases and their outbreaks in Asia-Pacific: biodiversity and its regulation loss matter. PLoS ONE 9:e90032.

Morand, S., et al. 2015. Assessing the distribution of diseasebearing rodents in human-modified tropical landscapes. Journal Applied Ecology 52:784-794. 
Morand, S., C. Lajaunie, and R. Satrawaha. 2017. Biodiversity conservation in Southeast Asia: challenges in a changing environment. Routledge EarthScan, London, UK.

Nieberding, C., J. Goüy De Bellocq, and S. Morand. 2005. The biogeography of host-parasite interactions: from nested assemblages to comparative phylogeography. Mammal Study 30:S87-S93.

Olival, K. J., P. R. Hosseini, C. Zambrana-Torrelio, N. Ross, T. L. Bogich, and P. Daszak. 2017. Host and viral traits predict zoonotic spillover from mammals. Nature 546:646-650.

Page, L. K., R. K. Swihart, and K. R. Kazacos. 2001. Changes in transmission of Baylisascaris procyonis to intermediate hosts as a function of spatial scale. Oikos 93:213-220.

Presley, S. J., C. L. Higgins, and M. R. Willig. 2010. A comprehensive framework for the evaluation of metacommunity structure. Oikos 119:908-917.

Pumhom, P., S. Morand, A. Tran, S. Jittapalapong, and M. Desquesnes. 2015. Trypanosoma from rodents as potential source of infection in human-shaped landscapes of SouthEast Asia. Veterinary Parasitology 208:174-180.

Ramsey, J. M., A. E. Gutierrez-Cabrera, L. Salgado-Ramırez, A. T. Peterson, V. Sánchez-Cordero, and C. N. IbarraCerdeña. 2012. Ecological connectivity of Trypanosoma cruzi reservoirs and Triatoma pallidipennis hosts in an anthropogenic landscape with endemic Chagas disease. PLoS ONE 7:e46013.

Rubio, A. V., R. Avila-Flores, and G. Suzán. 2014. Responses of small mammals to habitat fragmentation: epidemiological considerations for rodent-borne hantaviruses in the Americas. EcoHealth 11:526-533.

Salkeld, D. J., K. A. Padgett, and J. A. Jones. 2013. A meta-analysis suggesting that the relationship between biodiversity and risk of zoonotic pathogen transmission is idiosyncratic. Ecology Letters 16:679-686.
Sodhi, N. S., L. P. Koh, B. W. Brook, and P. K. L. Ng. 2004. Southeast Asian biodiversity: an impending disaster. Trends Ecology and Evolution 19:654-660.

Su, M., W. Li, Z. Li, F. Zhang, and C. Hui. 2009. The effect of landscape heterogeneity on host-parasite dynamics. Ecological Research 24:889-896.

Suzán, G., E. Marcé, J. T. Giermakowski, J. N. Mills, G. Ceballos, and R. S. Ostfeld. 2009. Experimental evidence for reduced rodent diversity causing increased hantavirus prevalence. PLoS ONE 4:e5461.

Tangkanakul, W., H. L. Smits, S. Jatanasen, and D. A. Ashford. 2005. Leptospirosis: an emerging health problem in Thailand. Southeast Asia Journal of Tropical Medicine and Public Health 36:281-288.

Truc, P., et al. 2013. Atypical human infections by animal trypanosomes. PLoS Neglected Tropical Diseases 7:e2256.

Van Vinh Chau, N., et al. 2016. A clinical and epidemiological investigation of the first reported human infection with the zoonotic parasite Trypanosoma evansi in Southeast Asia. Clinical Infectious Diseases 628:1002-1008.

Warren-Thomas, E., P. M. Dolman, and D. P. Edwards. 2015. Increasing demand for natural rubber necessitates a robust sustainability initiative to mitigate impacts on tropical biodiversity. Conservation Letters 8:230-241.

Watt, G., et al. 2014. Infective endocarditis in Northeastern Thailand. Emerging Infectious Diseases 20:473-476.

Wilcove, D. S., X. Giam, D. P. Edwards, B. Fisher, and L. P. Koh. 2013. Navjot's nightmare revisited: logging, agriculture, and biodiversity in Southeast Asia. Trends Ecology and Evolution 28:531-540.

Wood, C. L., A. McInturff, H. S. Young, D. H. Kim, and K. D. Lafferty. 2017. Human infectious disease burdens decrease with urbanization but not with biodiversity. Philosophical Transactions of the Royal Society B 372:20160122.

\section{SUPPORTING INFORMATION}

Additional supporting information may be found online at: http://onlinelibrary.wiley.com/doi/10.1002/eap.1886/full

\section{Data Availability}

Data are available from the Dryad Digital Repository: https://doi.org/10.5061/dryad.s6s9p58 